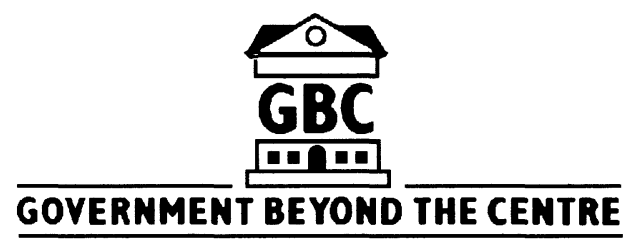

SERIES EDITOR: GERRY STOKER

The world of sub-central government and administration - including local authorities, quasi-governmental bodies and the agencies of public-private partnerships - has seen massive changes in recent years and is at the heart of the current restructuring of government in the United Kingdom and other Western democracies.

The intention of the Government Beyond the Centre series is to bring the study of this often-neglected world into the mainstream of social science research, applying the spotlight of critical analysis to what has traditionally been the preserve of institutional public administration approaches.

Its focus is on the agenda of change currently being faced by subcentral government, the economic, political and ideological forces that underlie it, and the structures of power and influence that are emerging. Its objective is to provide up-to-date and informative accounts of the new forms of government, management and administration that are emerging.

The series will be of interest to students and practitioners of politics, public and social administration, and all those interested in the reshaping of the governmental institutions which have a daily and major impact on our lives. 


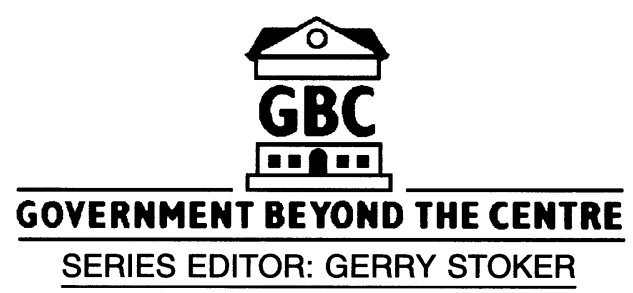

Published

Richard Batley and Gerry Stoker (eds)

Local Government in Europe

Clive Gray

Government Beyond the Centre

John Gyford

Citizens, Consumers and Councils

Richard Kerley

Managing in Local Government

Desmond King and Gerry Stoker (eds)

Rethinking Local Democracy

Steve Leach, John Stewart and Kieron Walsh

The Changing Organisation and Management of Local Government

Arthur Midwinter

Local Government in Scotland

Yvonne Rydin

The British Planning System

John Stewart and Gerry Stoker (eds)

Local Government in the 1990s

David Wilson and Chris Game (with Steve Leach and Gerry Stoker) Local Government in the United Kingdom

\author{
Series Standing Order \\ If you would like to receive future titles in this series as they \\ are published, you can make use of our standing order \\ facility. To place a standing order please contact your \\ bookseller or, in case of difficulty, write to us at the address \\ below with your name and address and the name of the \\ series. Please state with which title you wish to begin your \\ standing order. (If you live outside the UK we may not have \\ the rights for your area, in which case we will forward your \\ order to the publisher concerned.) \\ Standing Order Service, Macmillan Distribution Ltd, \\ Houndmills, Basingstoke, Hampshire, RG21 6XS, England
}




\title{
Rethinking Local Democracy
}

\author{
Edited by \\ Desmond King
}

and

Gerry Stoker

Published in association with the 
Selection and editorial matter (C) Desmond King and Gerry Stoker 1996 Individual chapters (in order) (C) Gerry Stoker, David Beetham, Keith Dowding, the estate of Kieron Walsh, Elizabeth Frazer, Anne Phillips, Hugh Ward, Harold Wolman, Mike Goldsmith, Allan Cochrane, Desmond King 1996

All rights reserved. No reproduction, copy or transmission of this publication may be made without written permission.

No paragraph of this publication may be reproduced, copied or transmitted save with written permission or in accordance with the provisions of the Copyright, Designs and Patents Act 1988, or under the terms of any licence permitting limited copying issued by the Copyright Licensing Agency, 90 Tottenham Court Road, London W1P 9HE.

Any person who does any unauthorised act in relation to this publication may be liable to criminal prosecution and civil claims for damages.

First published 1996 by

MACMILLAN PRESS LTD

Houndmills, Basingstoke, Hampshire RG21 6XS

and London

Companies and representatives

throughout the world

ISBN 978-0-333-63853-8 ISBN 978-1-349-24756-1 (eBook)

DOI 10.1007/978-1-349-24756-1

A catalogue record for this book is available from the British Library.

$\begin{array}{llllllllll}10 & 9 & 8 & 7 & 6 & 5 & 4 & 3 & 2 & 1\end{array}$

$\begin{array}{llllllllll}05 & 04 & 03 & 02 & 01 & 00 & 99 & 98 & 97 & 96\end{array}$

Copy-edited and typeset by Povey-Edmondson

Okehampton and Rochdale, England 


\section{Contents}

Notes on the Contributors vi

Preface viii

1 Introduction: Normative Theories of Local Government and Democracy 1 Gerry Stoker

2 Theorising Democracy and Local Government 28 David Beetham

3 Public Choice and Local Governance 50 Keith Dowding

4 Public Services, Efficiency and Local Democracy 67 Kieron Walsh

5 The Value of Locality $\quad 89$ Elizabeth Frazer

6 Feminism and the Attractions of the Local Anne Phillips

7 Green Arguments for Local Democracy Hugh Ward

8 Theories of Local Democracy in the United States Harold Wolman

9 Normative Theories of Local Government: A European Comparison

Mike Goldsmith

10 From Theories to Practices: Looking for Local

Democracy in Britain

Allan Cochrane

11 Conclusion

Desmond King

Bibliography

Index 


\section{Notes on the Contributors}

David Beetham is Professor in the Department of Politics, University of Leeds. His many publications include The Legitimation of Power (Macmillan, 1991) and Max Weber and the Theory of Modern Politics (1985, 2nd edn).

Allan Cochrane is Dean of the Faculty of Social Science, the Open University. He is author of Whatever Happened to Local Government? (1993) and co-editor (wirh James Anderson) of Politics in Transition (1989).

Keith Dowding is Lecturer in Public Choice and Public Policy in the Department of Government at the London School of Economics. $\mathrm{He}$ is the author of Rational Choice and Political Power (1991), and The Civil Service (Routledge, 1995) a number of journal articles and is co-editor (with Desmond King) of Preferences, Institutions and Rational Choice (1995) He is currently completing a major research project with four colleagues on the governance of London, as part of the Economic and Social Research Council's (ESRC) Local Government Programme.

Elizabeth Frazer is Fellow and Tutor, and University Lecturer, in Politics at New College, Oxford. She is the co-author (with Nicola Lacey) of The Politics of Community: a Feminist Critique of the Liberal-Communitarian Debate (1993), and is currently working on normative theories of political relations and public life.

Mike Goldsmith is Professor and Pro-Vice Chancellor at the University of Salford. He is the co-author (with Harold Wolman) of Urban Politics and Policy: A Comparative Approach (1992) and editor of New Research in Central-Local Relations (1986).

Desmond King is Fellow of St John's College, Oxford. His most recent book is Separate and Unequal: Black Americans and the US Federal Government (1995). 
Anne Phillips is Professor in the Department of Politics and Modern History, London Guildhall University. Her publications include Engendering Democracy (1991) and The Politics of Presence (1995).

Gerry Stoker is Professor of Politics, University of Strathclyde. He is Programme Director of the ESRC Local Governance Research Programme 1992-1997. His previous books include The Politics of Local Government (1991, 2nd edn), and co-editorship (with John Stewart) of Local Government in the 1990s (1995).

Kieron Walsh, who died in May 1995, was Professor of Public Sector Management and Director (designate) of the Institute of Local Government Studies at the University of Birmingham. He wrote on marketing, quality, competition and ethics in the public service, and had recently completed an ESRC local government research project on the new institutional framework. His recent publications include: Public Services and Market Mechanisms, (1995) and (with John Stewart and David Prior) Citizenship Rights, Communities and Participation (1995).

Hugh Ward is Senior Lecturer in the Department of Government at the University of Essex. His current research is in the fields of rational choice theory and environmental politics. His recent publications include (with D. Samways) 'Environment Policy', in R. Rhodes and D. Marsh (eds) Implementing Thatcherite Policies: Audit of an Era (1992); 'Game Theory and the Politics of the Global Commons', Journal of Conflict Resolution (1993); 'Purity and Danger: The Politicisation of Drinking Water Quality in the 80s', in M. Mills (ed.) Prevention, Health and British Politics (1993).

Harold Wolman is Professor in the Department of Political Science at Wayne State University, Detroit. He is co-author (with Mike Goldsmith) of Urban Politics and Policy: A Comparative Approach (1992) and (with Valerie Karn) Comparing Housing Systems (1992). 


\section{Preface}

This book is a product of the Economic and Social Research Council's (ESRC) Local Governance Programme. It emerged following two conferences sponsored by the ESRC and organised by Professor Gerry Stoker. The participants in the first conference at Strathclyde University on 20-21 May 1993 included:

John Benington

Desmond King

Kieron Walsh

John Gyford

Robin Hambleton

Vivien Lowndes

John Stewart

David Beetham

Hugh Ward

Mike Goldsmith

Patrick Le Gales
Hal Wolman

Davina Cooper

Ann Stewart

Margaret Hodge

Rod Rhodes

Jim Bulpitt

Dave Marsh

Karen Mossberger

Larry Rose

Gerry Stoker

The participants in a second conference held on 26-27 September 1994 at St John's College, Oxford, were:

John Benington

Desmond King

Kieron Walsh

Vivien Lowndes

David Beetham

Hugh Ward

Margaret Hodge
Allan Cochrane

Keith Dowding

Elizabeth Frazer

Anne Phillips

Hal Wolman

Mike Goldsmith

Gerry Stoker

The participants of both conferences contributed to the development of this book. We are grateful to them for their time and insights.

The discussions held at the two conferences were enjoyable and thought-provoking. The development of the book has been a challenge but we are thankful that our contributors proved themselves to be responsible and responsive. Helpful comments from two 
referees - George Jones and Geraint Parry - helped us to refine the project in its final stages. Jean McDougall and Neil McGarvey eased the process of production.

The book is dedicated to the memory of Kieron Walsh. He was a fine colleague and a good friend. His chapter was complete when he died of a heart attack in May 1995. Some minor editorial corrections have been made with the help of staff at the Institute of Local Government Studies.

Gerry Stoker 
In memory of Kieron 